\title{
The Biographical Turn: Lord Nottingham, His Case
}

\author{
David Saunders
}

\begin{abstract}
This article recalls Sir Heneage Finch (1621-1682) - better known as Lord Chancellor Nottingham - and in addition his contemporary, Sir Matthew Hale (1609-1676). Its focus is on their bearing of a 'persona' appropriate to the duties of judicial 'office' in the Restoration context of the Anglican settlement. The aim here is to demonstrate a biographical turn that is personal and historical but not anachronistic. The article proposes two descriptive protocols concerning 'office' and 'persona', and four revisions that impel this biographical turn to a more historical account of Lord Nottingham.
\end{abstract}

And for so much as the Court bridleth the rigour of the Common Law, by giving actions and exceptions for remedies where by Law none were, according to equity and conscience, to maintaine equum et bonum, the common people terme the Chancery the Court of Conscience; yet herein conscience is so regarded, that Lawes be not neglected, for they must joyn hands in the moderation of extremity. (William West, The second part of Symbolaeography, 1590)

\section{HistORICAL BACKDROP}

To propose a 'historical turn' that would return law and legal studies to their grounds in history is to give a timely signal. It has to be said though this is not my present polemic - that in recent years students of law have been more exposed to theoretic than to historical approaches to their subject. As yet we do not know for sure what will be the effects of long-term exposure to the glare of legal theory, especially when it is combined with under-exposure to the light of legal history. But there are grounds for concern.

A 'biographical turn' that would re-orient legal studies towards lifehistories of lawyers constitutes one among other elements of this broader intellectual re-direction of scholarly attention towards law's history. The fact that thousands of now nameless lawyers and jurists have played a crucial part in the history of Western nations' political and legal institutions does not disqualify a biographical turn to the historical lives of named officers of law, not least the occupants of judicial office in England. ${ }^{1}$

1 'It is generally known that the English common law is a creation of the royal judges and that the role of professors of law and of theoretical study - "legal science" - has in the course of the centuries been marginal. No contrast could be greater than between this English development and its continental counterpart, for there the impact of "professors' law" has been of the greatest importance. In fact, it is not too much to say that there are large and important fields of law which were created by continental jurists just as the English common law was 
This article will propose two protocols for making a biographical turn when describing early-modern judicial lives, taking the life of Sir Heneage Finch (1621-1682), better known as Lord Nottingham, as a case in point. I will use the appellation Nottingham, though strictly speaking this is anachronistic before Finch's 1681 elevation to the peerage as Earl of Nottingham. For me, this biographical turn to Lord Nottingham is in fact a return that has occasioned a substantial re-think concerning an English judicial figure whom I first considered quite some years ago. ${ }^{2}$ At that time I was intent on drawing a political diagram, not on sketching a judicial life history with appropriate attention to historical context.

Nottingham's was a life lived in political and religious circumstances that were anything but settled. Seventeenth-century England saw divine right monarchy, religious and civil wars, regicide, abolition of monarchy, puritan republican government, restoration of monarchy and re-establishment of an Anglican state-church. Six years after Nottingham's death in 1682, the Dutch military intervention of 1688 brought an improbable if brief co-presence of two armed princes of rival protestant and catholic confessions in the one territory, before the Stuart monarch James II fled his kingdom. It was the year of England's so-called Glorious Revolution.

To hear a voice of those times we can do no better than listen to the Thomas Hobbes of Behemoth, his devastating civil war report that recalls how credulous, priest-driven men had come to believe the fact of death less fearful than the phantasm of damnation. Recalling his English contemporaries' pursuit of their spiritual good by means of their confessional rivals' destruction, Hobbes concluded: 'How we can have peace while this is our religion, I cannot tell'. ${ }^{3}$ For those who won't listen to Hobbes, John Locke's 1689 Letter concerning toleration suggested why religious settlement was so elusive: 'For every Church is Orthodox to it self; to others, Erroneous or Heretical'. ${ }^{4}$ But religious uniformity promised civil peace. So settlement there was, and it was particular and Anglican.

This is the fractured backdrop to Lord Nottingham and his legal career. He was 28 when Charles I was beheaded in 1649. Appointed Solicitor-General in the 1660 Convention Parliament, he led the prosecution's case in the trial of the regicides. ${ }^{5}$ Two decades of ministerial office followed, as Solicitor-General (1660-1670), Attorney-General (1670-1673), Lord Keeper of the Great Seal (1673-1675) and Lord Chancellor from 1675.

the judges' handiwork': RC van Caenegem, Judges, Legislators and Professors. Chapters in European Legal History (Cambridge, 1987) 53.

2 David Saunders, Anti-lawyers: Religion and the Critics of Law and State (Routledge, 1997).

3 Thomas Hobbes, The English Works, vol VI, Behemoth: The History of the Causes of the Civil Wars of England, and of the Counsels and Artifices by Which They Were Carried On from the Year 1640 to the Year 1660, Sir William Molesworth (ed) (John Bohn, 1840) 235.

4 John Locke, A Letter Concerning Toleration, James Tully (ed), William Popple (trans) (Liberty Fund, 1983) 32.

$5 \quad$ See 5 State Trials 985 
His nine-year occupancy of these last two offices in the court of Chancery later earns him the honorific of 'Father of English equity'.

What first brought Lord Nottingham to my attention was his statement on conscience in Coke $v$ Fountaine, a case he heard in Chancery in 1676. I will cite this case and consider Nottingham's legal career more broadly, with a mention of his fellow judge, Chief Justice Sir Matthew Hale. To close, I will propose two descriptive protocols that concern 'office' and 'persona', specifically the shaping of a persona appropriate to the duties attaching to judicial office when exercised within a national context where the relations of religion, politics and law were comprehensively shaped by the Anglican settlement.

Nottingham was fully at ease adjudicating within the terms of this religious settlement that bound the Church of England and the public order of the Crown as one. By contrast, the moderate Puritan Hale worked painfully on himself in order to meet the necessary condition of exercising the office of judge in circumstances where 'Christianity is Parcel of the Laws of England'. In contrast with both Nottingham and Hale, an extra-judicial figure such as the radically anti-Anglican philosopher, the Dissenter John Locke, could elevate to an absolute principle of right the freedom of private conscience - and individual reason - from the state and its laws. ${ }^{6}$ For us now, the point is not to promote one of these three positions on conscience and the courts as the true one. All three have arguments going for them. The historical point, though, to see how the judges construed conscience in their mid-17th century Anglican order of things.

\section{COKE V FountaINe (1676)}

In Nottingham's report of Coke $v$ Fountaine, I seized on his demarcating of apparently antithetical forms of conscience, the religious and the political:

If after all this a man will still suppose that there was a secret trust, security or agreement between the parties to repurchase this rent, which no bill charges, no proof can make out, and the defendant denies upon oath, then it must be such a trust, security or agreement as is only between a man and his confessor. With such a conscience which is only naturalis et interna [natural and inner] this Court hath nothing to do; the conscience by which I am to proceed is merely civilis et politica [civil and political], and tied to certain measures. ${ }^{7}$

I took this demarcation between the two consciences, the one "natural and inner', the other 'civil and political', to be exemplary. Seventeen years ago, in Anti-lawyers, I was inspired by the great European religious peace settlements of Augsburg in 1555 and Westphalia in 1648. My aim was

6 On Locke's marginality to the settlement scene, see JGA Pocock, 'The myth of John Locke and the obsession with liberalism' in JGA Pocock and Richard Ashcraft (eds), John Locke: Papers Read at a Clark Library Seminar, 10 December, 1977 (Clark Library, 1980) 2-24.

7 Coke v Fountaine (1676) in DEC Yale (ed), Lord Nottingham's Chancery Cases, 2 vols (Selden Society and Bernard Quaritch, 1957) vol 1, 371. 
polemical: to depict today's relations between law and high-end theory as an analogue of historical relations between law and religion. I envisaged a fundamental historical separating of law from religion, as early-modern states emerged from confessional civil war to establish secular settlements. The lawyers - Nottingham included - became protagonists of what I then conceived as an epochal 'secularising' shift. ${ }^{8}$

Coke $v$ Fountaine was heard in May 1676 by Lord Nottingham with Chief Justices North and Rainsford. The case concerned two disputed leases and a rentcharge. It was to run from 1672 to 1690 in the Chancery, the King's Bench, the Exchequer and the House of Lords sitting as a court of equity. Robert Coke, the plaintiff, was cousin to John Coke, grandson of Sir Edward Coke, whose estate the Coke family inherited. At issue was John Coke's complex dealings with Andrew Fountaine, the defendant, whom he had met when they were students at the Inner Temple and with whom he had left England to travel the Continent. Coke granted Fountaine various enrichments and gifts, and made him an executor, perhaps with promises to protect his friend from other members of the Coke family should he, John Coke, die. He died in 1671, aged 36. The family at once proceeded to 'reclaim' properties they considered Andrew Fountaine to have purloined from their relative by 'fraud'. Litigation commenced in the King's Bench and the Exchequer, arriving before Lord Nottingham in the Chancery in 1676. In the conflict over who had invested whose moneys, at the last minute the plaintiffs dropped the fraud charge, wrong-footing Fountaine's defence. ${ }^{9}$

In Nottingham's expression of an apparently fundamental caesura between a strictly legal conscience and the sort of conscience 'as is only between a man and his confessor', I thought I had found not only textual grounds for my theoretical argument but also historical grounds for imputing to English law a novel sphere of autonomy from religion. As for the privileged 'relation as is only between a man and his confessor', I recorded that with this Nottingham's court had 'nothing to do', though the religious conscience could put a man sub pericolo animae before God. With the 'internal' conscience set aside as a spiritual matter to which English law was now indifferent, I piled on to Nottingham two mountainous hypotheses. First, that his statement on the 'conscience by which [he] was to proceed' confirmed that English law was reconstructing itself as 'secular' after the religious civil conflict, disengaging from theology to become independent of religious norms. Second, that Chancery was a setting for the historic de-confessionalisation of law.

8 Two recent studies illuminate respectively the more general issue of Chancery, conscience and casuistry in early-modern England and the specific case of Coke $v$ Fountaine. See Dennis R Klinck, Conscience, Equity and the Court of Chancery in Early Modern England (Ashgate, 2010) 219-261; and Mike Macnair, 'Coke v Fountaine' (1676) in C Mitchell and P Mitchell (eds), Landmark Cases in Equity (Hart Publishing, 2012) 33-61. As Macnair shows, for Nottingham, the 1676 Chancery case turned on the typology of trusts, whether express or implied.

9 For Nottingham, resolution of this secret trust, security or agreement between the parties was hampered by the lack of documents, proofs and evidence. See Macnair, above n 8, 33-56. 
Looking into Nottingham's career, I thought I found further confirmation. For instance, in the 'little treatise of chancery learning' that he compiled for his own professional purposes, he amplified the distinction between spiritual interior and legal exterior:

And yet all cases that are without remedy at common law are not relievable in equity: nor is the rule nullus recedat a cancellaria sine remedio [none leaves the Chancery without a remedy] so to be understood, for some cases are only to be considered between a man and his confessor. ${ }^{10}$

Returning to the case now, I see this less as a denial of effectivity to the religious conscience than a recognition that the law addresses only a part of the realm of conscience as a whole:

Yet God forbid a man should use no better conscience than the Chancery can compel him. However, the rule must always hold that it is not fit for a court of equity to do everything that is fit to be done: for there is a twofold conscience, viz. Conscientia politica et civilis et conscientia naturalis et interna. Many things are against natural and inward conscience which cannot be reformed by the regular and political administration of equity. For if equity be tied to no rule, all other laws are dissolved and everything becomes arbitrary. ${ }^{11}$

In setting aside the religious conscience, English law, it seemed to me previously, was divesting itself of a religious past.

In this 'secularising' vein, I also prized a judgment made the year before Coke $v$ Fountaine. Nottingham had excluded from legal liability a son who, in a promissory note, had undertaken to pay off his father's debt at a later date:

I said, if this note were voluntary and without consideration, though it did bind the son in honour and private conscience, with which I had nothing to do, it could not bind him in legal and regular equity. ${ }^{12}$

The contrast between a non-justiciable 'private conscience' and 'legal and regular equity' was more grist for my mill, a juristic delimitation of the clerical domain. If the historical norms of an ecclesiastical order were losing authority to emerging secular norms of law, that order would no longer represent the social whole. Looking at Nottingham's words now, I see a rather less grand statement: that guiding good conduct is not solely the preserve of the court, because 'honour and private conscience' too have their part to play.

A final instance of my pursuit of 'secularisation': in 1682, his final year of life, Nottingham adjudicated a contest over appointment to clerical office. In the hearing, to challenge the defendant's fitness to hold a lectureship (clergyship), plaintiff's counsel raised the issue of confessional identity. He did this by reiterating that his client's rival was a Presbyterian:

10 DEC Yale (ed), Lord Nottingham's 'Manual of Chancery Practice'and 'Prolegomena of Chancery and Equity' (Cambridge University Press, 1965) 194.

11 Ibid, 194.

12 Honywood v Bennett (1675) in DEC Yale (ed), Nottingham's Chancery Cases, vol 1, above n 7, 214. 
Mr Attorney ... harped much upon it that this lecturer was a Presbyterian and as soon as he had done in the church would run into a conventicle; and upon his repeating this matter so very often, the Lord Chancellor told him that he was not to be led or harangued with prejudice into a cause. It was not before him in this cause whether the man was a Presbyterian or not: he minded the matter only, not the man. ${ }^{13}$

I took Nottingham's excluding of confessional identity from legal relevance as further evidence that the legal order was becoming 'secularised' as a step towards civil peace in England.

Not that a religious peace settlement was a trivial issue. The circumstances of 1682 remained fraught and violent as competing Christian currents provoked communal hatreds. Anxieties heated by the 'Popish Plot' of 1678-1679 had somewhat cooled, but fear had been re-heated by a 'Phanatick Plot' of republicans and socinians against Anglicans and loyalists. To tarnish a defendant as 'Presbyterian' carried the stigma of religious extremism. It shaded nicely into 'Phanatick' and 'Sectary', hence one who was 'ready to run into a conventicle'. So when Nottingham delimited his courtroom's discourse to 'the matter only, not the man', I welcomed this as further textual confirmation that an English legal sphere was being 'secularised'.

But now some recanting is called for. It entails more than a 'biographical turn'. The generalising term 'English legal sphere' over-unifies the jurisdictional plurality of law in Nottingham's England. Despite the consolidation of legal administration in the curia regis, collateral with Chancery and the Exchequer were not only the canon law courts and the civilian Doctors Commons, but also the jurisdictional plethora itemised in Sir Edward Coke's 'On the Jurisdiction of Courts'. These included the courts of the steward of the King's household; leets (victuals and drinks); piepowders (markets and fairs); commissioners of sewers; forests; staple (wool, leather, metals); stannaries (mines); universities; clerk of the market (weights and measures); commissioners of beacons, lighthouses and seamarks; the counting house; ambassadors; and the King's swanherd. Coke's inventory does not extend to the city and guild courts so important to the civic and commercial life of the times.

The key issue, though, was the relation of law and religion. Seventeen years ago, when I looked at Lord Chancellor Nottingham, I was drawing a political diagram, not sketching a legal life history. I was transposing to 17th century England a template fitting other nations' religious, political and legal histories, not least the history of the German absolutist territorial state of Brandenburg where jurists had deployed the resources of an Imperial jus publicum to fashion a political-juridical order distinguished by its official neutrality towards rival post-Reformation confessions. ${ }^{14}$

13 Saunders, above n 2, 28, quoting Hale in Man v Ballet (1682) 1 Vernon 43, 44.

14 My previous view of Nottingham in England was coloured by the account of absolutist state formation in Reinhart Koselleck, Critique and Crisis: Enlightenment and the Pathogenesis of Modern Society (MIT Press, 1988). 
I was also transforming an English chancellor into a follow-up version of Michel de l'Hospital. A century earlier, the French chancellor had confronted religious civil conflict in his country. In 1562, during the first of France's eight wars of religion, l'Hospital put the Crown's case to the peace 'colloquium' at St-Germain-en-Laye:

It is not a question of establishing the faith, but of regulating the state. It is possible to be a citizen without being a Christian. Even the excommunicate is nonetheless a citizen. You do not cease to be a subject of the King when you separate from the Church. We can live in peace with those who do not observe the same ceremonies. ${ }^{15}$

'Even the excommunicate is nonetheless a citizen'. Such a precept - underpinned by l'Hospital's neo-platonism - conceived the community of citizenship as a unifying super-eminent domain transcending the temporarily fractured confessional domain. ${ }^{16}$

With l'Hospital we glimpse the possibility of settling religious conflict by applying law rather than by invoking religious truth. Legal means promised a modus vivendi and a public order acceptable to Huguenots and Catholics. The disposition of the judiciary was crucial. In 1563, l'Hospital confronted the judges of the Rouen parlement with his definition of the judicial function in this time of religious conflict: 'Vous estes juges du pré ou du champ, non de la vie, non des moeurs, non de la religion'. ${ }^{17}$ He was calling for an extraordinary act of confessional abeyance. In the event, incompatible confessional identities proved stronger than the chancellor's appeal to law's civility, judges' impartiality, and a peaceful public observance of Christian pieties. My temptation was to have Nottingham re-appear in the after-glow of Michel de l'Hospital. ${ }^{18}$ But this is now a temptation to resist.

\section{Four REvisIONs}

To make a biographical turn towards a more historical account of Lord Nottingham, I propose four points of revision. First, on his use of the law for religious purposes. Second, on the dual conscience question. Third,

15 Michel de l'Hospital, Oeuvres complètes de Michel de l'Hospital, 2 vols, vol 1, PJS Dufey (ed) (Paris, 1824) 452.

16 On the case for an 'autonomisation of political reason' arising from the work of l'Hospital, as well as from legal development of bi-confessional courts or chambres mi-parties and from local community initiatives for civil peace between Catholics and Huguenots, see Olivier Christin, La paix de religion. L'autonomisation de la raison politique au XVIe siècle (Seuil, 1997).

17 English translations can be more plain, as in 'You are judges of acts, not of lives, morals or religion'. See David Potter (ed), The French Wars of Religion (Macmillan, 1997) 88.

18 See Denis Crouzet, La sagesse et le malheur. Michel de l'Hospital, Chancelier de France (Champvallon, 1997) 324. Crouzet allows that l'Hospital aimed to install 'a mode of power grounded in a strategy of bypassing cleavages and opinions ... a constant practice of depersonalisation of the magistrate, master of his passions and of the passions of men, a being without preferences'. 
on Nottingham's gestures of demarcation. Fourth and finally, on his procedural reference to 'certain measures'.

First point of revision: Nottingham's use of the law for religious purposes. The particular English path to an early-modern civil order led through the State's incorporation of a relatively inclusive national church into the English constitution. The Anglican confessional state was the setting for Nottingham's legal career. As a parliamentarian and high judicial officer of State, he played his part in the installation of an Anglican orthodoxy.

To safeguard the Anglican order from threats perceived or real, the English Parliament legislated vigorously on the twin matters of religion and public order. ${ }^{19}$ The Corporation Act 1661 (UK) imposed a sacramental test for holders of public offices of trust. Failure meant ejection of aldermen of doubtful adherence to the Church of England, of uncertain allegiance to the Crown and therefore not to be trusted in business. The Act of Uniformity 1662 (UK) and the two Test Acts 1673 and 1678 (UK) required subscription to the Thirty-nine Articles of the Church of England and made a declaration against transubstantiation as mandatory for admission to the national church, the 'test' being designed as a threshold measure to protect the institutions of state and civil administration by blocking 'Papists' from occupancy of military and civil offices. The aim of the Act for Restraining NonConformists from Inhabiting Corporations 1665 (UK) is self-evident.

To regulate the forms of public worship, Parliament passed a new Conventicle Act in 1664 and another in 1670, following the 1593 Conventicle Act. The 1664 legislation maintained the penal sanctions of the earlier statute, including imprisonment pending conformity, failing which property was forfeited and abjuration under oath demanded. Religious gatherings of more than five 'Dissenters' were made a criminal act, with a scale of fines for attendance at unauthorised meetings. A third offence incurred the penalty of transportation. The 1664 Act lapsed after three years, but was replaced in 1670 by new legislation making mere attendance at a conventicle a lesser offence, though organising and preaching were heavily fined. In 1672, however, some licences were granted to some dissenting conventicles.

Strange though it be to our eyes, these ecclesiastical security measures were political expressions of the divine will in 17th century England. ${ }^{20}$ They sealed an alliance of state and church. From 1660 to 1682, Nottingham contributed to this convergence of state, law and the national religion. Public worship was inseparable from public order. We find him in Parliament in April 1675, asserting that 'religion, as it works upon the conscience, ... the state has nothing to do with it'. But if we read

19 See JCD Clark, English Society 1660-1832: Religion, Ideology and Politics During the Ancien Regime (Cambridge University Press, 2000) 43-123.

20 Parliament did not repeal the Corporation and Test Acts until the 19th century, and even then resistance remained. See GIT Machin, Politics and the Churches in Great Britain, 1832-1868 (Clarendon Press, 1979). 
on in the Journal of the House of Lords, we see he was recommending a religious test to guarantee public safety against the threat of religious discord. Perhaps there was no contradiction. The law did not seek to constrain the sanctity of inner conscience, but to ensure an English civic life now framed by an Anglicanism that had to be defended against known sectarian dangers.

In office as Lord Chancellor, Nottingham's duty was to defend civil order by protecting the state religion. In an undated manuscript, we read his instructions to the circuit judges:

To get to the Root of this matter whenever you meet with any Popish preists [sic] or Jesuits you are to proceed effectually to their Attainder and Condemnation of High Treason. ${ }^{21}$

Execution of sentence was to wait 'until the King's pleasure be further known that so they remain as Hostages ready to be made a publique sacrifice whenever that party shall go about to disturb our Peace'. Catholic Recusancy was just one element of a general threat to Anglican order:

[T] he Papists are not the only men to have separated from us upon account of Religion. There are other men who tell us they are of our Religion and yet separate from us too, and think themselves concerned for the Salvation of their Souls to oppose all our Laws and Constitutions. Now whether he be a Papist or a Fanatic that thus thinks the Mischief of the Government is still the same, and the same Principle will never fail to produce the same Effect, that is when ever there is any probable Opportunity of making a Disturbance their quarrel is the Government shall be called the Cause of God and of Religion. No State can long subsist under such Convulsions as these. ${ }^{22}$

Nottingham then demands the full force of the law be used against Protestant dissenters: 'the Pastors and Teachers, who gather these separate Congregations'. Even if for the moment their activities 'be only in a spiritual sense, God knows how soon it may end in an Other'.

The 'other men who tell us they are of our Religion and yet separate from us too' is a stark reminder that English Protestant Christianity was anything but homogeneous and unitary. Nottingham's notes convey the clear sense of a present danger posed by sectarian anarchists and doctrinal heretics: 'Great care therefore need be taken of these men, for Sedition in a Prayer is like Poison in Antidote - the Death is certain and inevitable'. ${ }^{23}$ These words stand in acute contrast to those of a Michel de l'Hospital reminding his judges that they were judges of the meadow or the field, not of life, not of morals, not of religion'. The same is true of Nottingham's official pronouncements, for instance his 1676 address on Serjeant Scroggs' admission to the Court of Common Pleas: 'The administration of Justice is ... so divine and so sacred an employment that he who enters upon it may in some sense be said to enter into religion'. ${ }^{24}$

21 Finch Papers, Box 4966: LAW 8, Leicestershire County Record Office.

22 Ibid.

23 Ibid.

24 Yale (ed), Nottingham's Chancery Cases, vol 1, above n 7, 436. 
Second revision: the dual conscience question. Where previously I'd seen in Coke $v$ Fountaine a modern 'secularising' boundary being drawn, I now note that the figure of the two consciences was in common use. James I thought his duty of office as king coextensive with his private conscience, as did Charles I. With the Anglican settlement, though, the known Catholic sympathies of Charles II and James II meant that royal religious and political consciences no longer coincided. Nonetheless, Nottingham stayed with the late-16th century view of the Lord Chancellor as administrator of the royal conscience, the Chancery serving as 'a back door for the King's Arbitry'. ${ }^{25}$ He thus referred to the role of all courts 'which hold pleas in equity' as being to 'administer the conscience of the King'. ${ }^{26}$

Puritan antagonists of the Church of England used the figure too - but for their own 'secessionist' ends - when asserting in Lockean manner the absolute primacy of the inner conscience that God had programmed in certain right-thinking persons. The radical Protestant polemicist John Milton's program was to deny kings, judges, bishops and priests any authority whatsoever over the inner conscience. In 1660, Milton's imprisonment was ordered for having written and published Pro populo anglicano defensio, a justification of the execution of Charles I. SolicitorGeneral Nottingham held that Milton deserved hanging.

However the demarcation of the two consciences is named - 'natural and inner' or 'civil and political', in foro interno or in foro externo - I no longer make the figure of the two consciences such a live issue, preferring to see Nottingham's use of the figure not as evidence of an epochal shift of law away from religion, but as a circumstantial statement made to specify his conception of the nature of the judicial office under the Anglican settlement. Rather than treating Coke $v$ Fountaine as the marker of a judicial constraint on the scope of the 'confessional' conscience, Nottingham is better viewed as setting limits to the juristic conscientia politica et civilis.

Third revision: Nottingham's exercise in demarcation. What I had taken to be a 'secularising' posture can be viewed as a jurisdictional claim. In Coke $v$ Fountaine, his demarcation of the two forms of conscience was 'jurisdictional' in the sense that he placed the 'secret' agreement between the contesting parties, an agreement lacking in formal proof, across the threshold demarcating his juridical domain from the confessional-moral domain. The Chancery jurisdiction had religious origins - early chancellors were churchmen - but by Nottingham's time it had long been a 'temporal' court. It avoided abolition under the Puritan regime, the 1653 Parliament vote to abolish the court remaining unimplemented. Unlike the Star Chamber and the Church of England - the latter had to be re-established in 1662 - Chancery survived the Interregnum to operate, from the Restoration, within the terms of an Anglican settlement.

Nottingham confronted other jurisdictional border-disputes. One lay between Chancery and the House of Lords sitting as an appellate court,

25 Cited in Klinck, above n 8, 223.

26 Yale (ed), Prolegomena, above n 10, 185. 
something he disliked. If in Chancery he had dismissed their bill, an unhappy plaintiff would dash up to the Lords - when the Lords were in session - and have their case heard. All within Westminster Hall, there was equity 'above stairs' - the Lords - and equity 'below stairs' - the Chancery. Just as Nottingham disliked losing business to the rival court 'upstairs', so the common lawyers defended their turf against Chancery's incursions. Specifically, it seems, when litigants asked the Chancellor to intervene in circumstances where they had entered into an obligation which they later wanted to escape on grounds of some equitable consideration. Sitting in Chancery, Nottingham was judge of law and fact. The courts of law had lay triers of fact, the popular juries. The common lawyers would adopt procedures that curtailed chances of intervention by the Chancellor. It was a matter of grabbing the best business, perhaps a darker side of legal pluralism.

Fourth and final revision: the procedural dimension. In his 'little treatise of chancery learning', Nottingham writes of 'the regular and political administration of equity'. ${ }^{27}$ From the time of the Tudor jurist, Christopher St German, 'conscience' and 'equity' carried an Aristotelian sense of a natural justice that transcended positive law. This higher 'sense' empowered chancellors to resolve cases involving circumstances that - in all their 'rigour' - common-law forms of action did not cover. But there was a problem: transcendence could mean arbitrariness, even despotism. ${ }^{28}$ The problem was set out famously in John Selden's gibe:

Equity in Law, is the same that the Spirit is in religion, what every one pleases to make of it. ... Equity is a roguish thing; for Law we have a measure [and] know what to trust to. Equity is according to the Conscience of him that is Chancellor and as that is larger or narrower so is Equity. 'Tis all one as if they should make the standard for the measure we call a foot to be the Chancellor's foot. What an uncertain measure would this be. One Chancellor has a long foot, another a short foot, a third an indifferent foot. 'Tis the same thing in the Chancellor's conscience. ${ }^{29}$

As Nottingham put it, if equity be tied to no rule, all other laws are dissolved and everything becomes arbitrary'..$^{30}$ Regarding conscience, he set out his procedural remedy in Coke $v$ Fountaine: 'the conscience by which I am to proceed is ... tied to certain measures':

and it is infinitely better for the public that a trust, security or agreement, which is wholly secret, should miscarry, than that men should lose

27 Ibid, 194.

28 Through the 17th century, the Chancery was criticised as an exercise of a single man's judgment that was arbitrary yet absolute. See, for instance, Robert Atkyns, An Enquiry into the Jurisdiction of the Chancery in Causes of Equity (London, 1695).

29 John Selden, The Table-Talk of John Selden (John Russell Smith, 1856) 49. Selden's manuscript was dedicated to Sir Matthew Hale, a close friend, when Hale was on the Common Pleas. On conscience, Selden observed at 38: 'If we once come to leave that outloose, as to pretend Conscience against Law, who knows what inconvenience may follow?' 
their estates by the mere fancy and imagination of a chancellor. The rule of nullus recedat a cancellaria sine remedio was never meant of English proceedings, but only of original writs, when the case would bear one; and so the Chancellor in 5 Hen 7, understood it, for otherwise says he, no man need to be confessed. ${ }^{31}$

But how to achieve measures that are certain? This was not a matter of shifting legal judgments out of religion but out of the uncertainty that threatens when an excessively 'equitable' discretion becomes arbitrary. Nottingham recognised the issue in reporting the Earl of Feversham's case: 'Justice is a severe thing and knows no compliance nor can bend itself to any man's conveniences, and equity itself would cease to be Justice if the rules and measures of it were not certain and known. For if conscience be not dispensed by the rule of science, it were better for the subject there were no Chancery at all than that men's estates should depend upon the pleasure of a Court which took upon itself to be purely arbitrary. ${ }^{32}$

Nottingham's solution: a 'regular and political administration of equity'. In one respect, this 'administration' simply meant aligning the 'extraordinary' jurisdiction of Chancery more closely with the common process of the 'ordinary' law: 'In suits in equity ... the Lord Chancellor must order his conscience after the rules and grounds of the laws of this realm'. ${ }^{33}$

This disposition found concrete expression in Nottingham's major literary initiative: his systematic recording of his own judgments in Chancery. From his nine years of judicial office, Nottingham reports 1170 cases. David Yale observes that under Nottingham and in light of his reporting practice, 'Chancery passes from the era of conscience to that of equity'. ${ }^{34}$ Case reports showing these 'certain measures' render the limits of equity less arbitrary. With Nottingham's reports, positive rules in equity jurisdiction were displacing discretionary judgments with recorded precedents. Does the writing of reports create precedents that then have general use? Or does a desire for accessible collections of precedents lead to production of reports? This remains a chicken-and-egg thing.

With these four points of revision, I am closer to describing Nottingham in biographical terms he would understand. ${ }^{35} \mathrm{He}$ would have shaken his head at my earlier account of him as a proto-seculariser, given the context in which he lived. Nottingham was born three years after the Thirty

31 Coke v Fountaine (1676) in Yale (ed), Nottingham's Chancery Cases, vol 1, above n 7, 371.

32 Earl of Feversham v Watson (1678) in Yale (ed), Nottingham's Chancery Cases, vol 2, above n 7, 639 .

33 Yale (ed), Prolegomena, above n 10, 200.

34 DEC Yale, 'Introduction' in Yale (ed), Nottingham's Chancery Cases, above n 7, xxxviii.

35 My downgrade of Nottingham's demarcation of two consciences in Coke $v$ Fountaine from epochal threshold of secularisation to statement of jurisdictional limits finds confirmation in Macnair's observation that the case was not in fact reported until the 19th century, with Swanston's 1827 printing of Nottingham's report. See Macnair, above n 8, 35-37. 
Years War began. He was 27 when the Religious Peace of Westphalia was signed. He survived the English religious civil wars and the mid-century's wild 'swarms of sectaries'. He observed the late Stuarts at close quarters and - being an Anglican supremacist - he resisted their policy of favouring religious indulgence and 'tolerating' a measure of religious dissent. ${ }^{36}$ Three years after his death, when Louis XIV revoked Henri IV's Edict of Nantes, Protestant Europe feared total annihilation.

A biographical turn, then, recognises that a 17th century English judge's relation to religion was material to how he fashioned a persona for judicial office in a particular set of national circumstances. Admitted to the Inner Temple in 1638 - aged 17 - Nottingham was orthodoxly episcopalian in a way that eased accommodation with the Anglican settlement. During the years of the Presbyterian regime - he termed the period of the Civil War and the Commonwealth 'the late ill times' - he retreated to a remunerative private practice. But with the 1660 Restoration, Nottingham enters the English political, legal and religious scene to play the role I have described.

As to his legal formation proper, he followed his lawyer-uncle's advice: that a law student 'ought to read all morning and talk all afternoon'. Nottingham read the Yearbooks, compiled his commonplace book and attended cases in the royal courts. Mastery of the ars bablativa was essential, not least for the evening disputations in the Inns of Court, almost certainly on such classic topics as the role that a judge's private conscience should play in his adjudication of cases.

\section{Sir Matthew Hale}

Other lawyers too declined judicial office in 'the late ill times', unwilling to take the Oath of Engagement demanded by the Cromwellian regime. For Sir John Vaughan, it was the Duty of an honest Man to decline, as far as in him lay, owning Jurisdictions that derived their Authority from any Power, but their lawful Prince'. ${ }^{37}$ Sir Matthew Hale (1609-1676), though, served under both Cromwell and Charles II, taking the Engagement in 1649 so that the ordinary laws could be kept running and administered - usurper or no usurper - for the sake of what he took to be the more essential continuity of the common law, the priority of civil order and the greater public necessity of the Kingdom. Following appointment in 1654 to the Court of Common Pleas - he'd have heard Nottingham pleading there as counsel - Hale served as Chief Baron of the Court of Exchequer (1660-1671) and, from 1671, as Chief Justice in the Court of King's Bench.

Nottingham and Hale had common ground, the younger man being a protégé and - after Hale's death - drafting a note on Hale for Gilbert

36 The title of the 1689 legislation speaks volumes: 'Act for Exempting their Majesties' Protestant Subjects Dissenting from the Church of England from the Penalties of Certain Laws'.

37 Richard Tuck, Natural Rights Theories: Their Origin and Development (Cambridge University Press, 1979) 115, quoting Sir John Vaughan. 
Burnet's 1692 Life and Death of Sir Matthew Hale. Nevertheless, it is hard to imagine the Anglican Nottingham penning the Puritan Hale's words on religion: I do 'not think that the essence of the Christian religion consists in this or any other particular form of government'. Concerning religion, Hale wrote:

It is pitiful to see men make these mistakes; ... one holding a great part of religion in pulling off the hat, and bowing at the name of Jesus; another judging a man an idolater for it; and a third placing his religion in putting off his hat to no one; and so like a company of boys that blow bubbles out of a walnut shell shall every one run after his bubble and call it religion. ${ }^{38}$

But like Nottingham, Hale had no doubt as to the public dangers of 'inspired' religion: 'he that today pretends an inspiration or a divine impulse to disturb a minister in his sermon tomorrow may pretend another inspiration to take away his goods or his life'. ${ }^{39}$

Like Nottingham, Hale saw civil order as under threat from unloosed spiritual enthusiasms in a context where 'the concerns of religion and the civil state are so twisted one with another that confusion and disorder and anarchy in the former must of necessity introduce confusion and dissolution of the latter' ${ }^{40}$ This is a striking statement. It reveals a judge who was not an Anglican nonetheless coming to see what the Anglican settlement meant in practice for those in judicial office: the Anglican order of things now made it impossible to plead 'the concerns of religion' against the laws of the Anglican 'civil state'. To occupy the office of judge in these circumstances, a persona had to be shaped.

In his private journal, Hale identifies the attributes that 'become a man of such employment' as a judge. He counsels himself that, 'I be not too rigid in matters conscientious, where all harm is diversity of judgment'. ${ }^{41}$ He cautions himself against leniency to persons accused but making claims of conscience. Leniency would 'utterly enervate all the power of [the] magistrate, for [conscience] sets up in every particular subject a tribunal superior to that of the magistrate'..$^{42}$ It sounds almost like Hobbes, warning against those who claimed their private 'conscience' justified their acting in the name of an authority higher than the sovereign's law. Of course, Hale was not re-staging the philosopher's absolutist defence of sovereignty. He was formulating a judgment within the prevailing circumstances of an Anglican ordering of religion and politics that now

38 Edmund Heward, Matthew Hale (Robert Hale, 1972) 127, quoting Hale.

39 Matthew Hale (Lambeth MS 3497, fol 26) in Alan Cromartie, Sir Matthew Hale (1606-1676) Law, Religion and Natural Philosophy (Cambridge University Press, 1995), 177.

40 Ibid.

41 This was among the guidelines that Hale formulated for his own conduct of judicial office following admission to the Court of Common Pleas. They were published in Sollom Emlyn's 'Preface' to his 1736 edition of Hale's Historia placitorum coronae: The History of the Pleas of the Crown (Nutt and Gosling, 1736). See also Heward, above n $38,67$.

42 Matthew Hale (Lambeth MS 3507, fol 32) in Cromartie, above n 39, 181. 
aligned the public conscience of the national Established Church with the public authority of the English crown.

This alignment found its confirmation - and drew Hale's acceptance - in his 1676 judgment in Taylor's case. It was a case where the 'spirit' had moved one, Taylor, to inform the world that, 'Christ is a whoremaster, and religion is a cheat and [Protestant] profession a cloak, and all cheats, all are mine, and I am a King's son and fear neither God, devil nor man'. This was textbook blasphemy. With Hale's judgment, blasphemy was made a religious-civil offence in tune with the process whereby Anglican observance was being made a condition of full participation in English civil life:

[S]uch a Kind of wicked blasphemous words were not only an Offence to God and Religion, but a Crime against the Laws, State and Government, and therefore punishable in this Court. For us to say, religion is a Cheat, is to dissolve all those Obligations whereby Civil Societies are preserved, and that Christianity is Parcel of the Laws of England; and therefore to reproach the Christian religion is to speak in Subversion of the Law. ${ }^{43}$

Taylor was 'fined 1000 mark, imprisonment until securities for good behaviour for life, and pillory at Gilford [Guildford] where the words were spoken, and at Westminster, Cheapside and Exchange, with a paper for horrid blasphemy, tending to subvert all government'. At risk was a civil order both confessional and juridical, resting on the Church of England and the English common law. ${ }^{44}$

Yet dissent continued. Some pursued forms of religious life way outside the norms of the Anglican order, posing dilemmas for the courts of law. How, for instance, was the public conduct of Quakers to be treated? Hale and Nottingham worked in the legislative context of an English state pursuing a confessional politics with the so-called Quaker Act 1662 (UK). This statute concerned Dissenters who refused all oaths. Self-appointed as God's most devoted 'saints' and His word's most faithful messengers, Quakers readily broke the laws of the land when 'inner light' and the higher law of the Spirit so demanded.

Quaker law-breaking was not confined to actions such as refusal to take or to be bound by an oath, refusal to pay tithes to the national Church or refusal to doff the hat to a social superior. Nor was Quaker conduct limited to occasionally going naked in public, an action we might now consider peaceful civil disobedience. Quaker law-breaking extended to conducting their own marriages and burials and to abusive interruptions of church services, actions that risked provoking public violence.

Hale accepted religious offences such as public blasphemy and witchcraft as both fact and civil threat, directly justiciable in the secular courts.

$43 \quad$ Saunders, above n 2, 56, quoting Hale.

44 Hale's 1676 precedent is cited in Sir William Blackstone, Commentaries on the Laws of England (Clarendon Press, 1765-1769) Book iv, 59. Blackstone endorses Hale's judgment. Unlike heresy, now a private heterodox opinion and therefore beyond the reach of the criminal law, blasphemy like Taylor's undermined the public authority of the Anglican order and was therefore to be judged a public matter. 
While trying two women 'witches' in 1662 in Bury St Edmunds, Hale thus composed a personal reflection to satisfy his private conscience, to reassure himself that the criminal punishment of witchcraft as the 'work of the devil' was just, being affirmed in Scripture and in the laws of England. Yet he was becoming uncertain as to how to treat 'religious' actions whose 'truth' - being 'secret' and not externalised in a justiciable act - was known to God alone..$^{45}$ By 1676 , in his Historia placitorum coronae, the criminal law treatise of which he had drafted one of three projected books before his death, Hale records that the common law viewed witchcraft - along with 'fascination' or enchantment - as among those 'secret things [that] belong to God':

If a man either by working upon the fancy of another, or possibly by harsh or unkind usage put another into such passion of grief or fear, that the party either die suddenly, or contract some disease, whereof he dies, though as the circumstances of the case may, this may be murder or manslaughter in the sight of God, yet in foro humano it cannot come under the judgment of felony, because no external act of violence was offered, whereof the common law can take notice, and secret things belong to God. ${ }^{46}$

If the ties between law and religion were tightening regarding blasphemy and sedition, they were loosening where witchcraft and 'fascination' were concerned. The judge's uncertainty may explain why Quakers who came before Chief Justice Hale recorded their appreciation of his moderation. ${ }^{47}$

\section{Two Protocols for a Biographical Turn}

Regarding Chancery, Hale had the common lawyer's habitually demeaning disposition: 'a little law, a good tongue and a good memory would fit a man for the Chancery'. Such dismissiveness brings us back to Nottingham's biography. A key source remains David Yale's 'Biographical sketch' in the 'Introduction' to his Selden Society edition of Lord Nottingham's Chancery Cases. ${ }^{48}$ Yale's focus on legal technicalities in equitable doctrine and procedure allows for few lighter touches, though he records Nottingham's writing to his son in 1666: 'I play at bowls, and ride abroad, and read ballads' ${ }^{49}$ That was the year London burned, the devilish work of Papists, of this Nottingham had no doubt. ${ }^{50}$

45 The report is published in 'A Trial of Witches', Cobbett's Complete Collection of State Trials and Proceedings for High Treason and Other Crimes and Misdemeanours, VI: 687-702 (London, 1809).

46 Matthew Hale, Historia placitorum coronae (London, 1736) n 38, 429.

47 See CW Horle, The Quakers and the English Legal System, 1600-1688 (University of Philadelphia Press, 1988) 260.

48 Yale, 'Introduction', above n 34.

49 Ibid, xxi.

50 Yale, 'Introduction', above n 34, xxvii, on Burnet's report of Nottingham's speech on the occasion of the 1680 trial of Lord Stafford for high treason in participating in the Popish plot. 
The biographical turn invites us look more widely than Selden Society footnotes allow. We could look, for instance, to the superb edition of The Conway Letters where Marjorie Hope Nicolson recounts events such as the second marriage of Nottingham's father, Heneage Finch the elder. In 1629, the latter's marriage to Elizabeth Bennet, the widow of Londoner, Alderman Bennet, was 'the culmination of one of the most amusing courtships London had known for many a year':

The rich widow - undoubtedly the catch of the season - was beseiged by many suitors, the most ardent of whom were a trio whose names afforded vast amusement to the gossips - Raven, Crow and Finch. The impetuous Doctor Raven, indeed, precipitated matters, for, unable to bear the suspense ... he forced himself into his lady's chamber at night, and by his fervor made himself the laughing-stock of London, for he was promptly handed over to a constable, and the next day found himself hauled before - of all people! - Recorder Finch [Nottingham's father], who expeditiously committed his rival to the gaol until the next sessions. ${ }^{51}$

With the widow's wealth, Finch bought Kensington House, later Kensington Palace and home to Princess Diana. Samuel Pepys - an avowed admirer of Nottingham's eloquence - records visiting the garden, 'singing there with the ladies, and a mighty fine cool place it is'. ${ }^{52}$

A nice anecdote, but it invites an important observation on the genre of writing. Where does the historical-biographical genre transpose to a 'novelistic' genre? Is it where historical description gives way to talk of essential selves? As, for instance, when Marjorie Hope Nicolson offers a character sketch of Nottingham: ' $[\mathrm{H}]$ is character, like his oratory, was crystal-clear, and, like crystal, inflexible and hard. All his life, in public and in private, Heneage Finch lacked shadows'. ${ }^{53}$ There's a genre boundary between life-history and novel, as there is between persona and self. ${ }^{54}$ This requires us to consider the terms in which we deal with Nottingham's family context.

In Anti-lawyers, I drew a contrast between Nottingham and his younger half-sister, Anne Finch, Lady Conway. What I knew about her was the usable fact that - unlike the 'secularising' lawyer - she had 'scandalously' converted to Quakerism, despite being married to Viscount

51 Marjorie Hope Nicolson, The Conway Letters, S Hutton (ed) (Clarendon Press, 1992) 3-4.

52 Samuel Pepys, The Diary of Samuel Pepys, 14 June 1664.

53 Nicolson, above n 51, 3.

54 While not concerned with early-modern subjects, Stuart Macintyre senses the 'rules' that come into play at the genre boundary between life-history and novel: 'Biography presents in a particularly marked form the limits imposed by the rules of historical interpretation. Put simply, the rules lay down that you must report the evidence faithfully: you can't go beyond the evidence, and you can't withhold evidence of significance. Observance of the rules deprives the historian of the resources of the novelist: you can't invent incidents, or adapt or reorganise them to sharpen the circumstances and raise the stakes. You can't contrive dialogue to dramatise interactions, nor can you have recourse to interior monologues in order to explore the thoughts and feelings of the actors'. See Stuart Macintyre, 'What makes a good biography?' (2011) 32 Adelaide Law Review 7, 8. 
Edward Conway, Secretary of State to Charles II. Anne Conway received visits from the great founding Quakers, George Keith, William Penn and George Fox, founder of the Society of Friends in 1648. What is more - here Quakerism's historical links with the European spiritual-intellectual 'underground' come into play - she gave space to the pan-European mystic, Franciscus Mercurius van Helmont, who set up an alchemical laboratory at Ragley Hall, her Warwickshire house. From van Helmont Anne Conway learned the Jewish Kabbala. So in Anti-lawyers I could write: "It was in this cultural setting that Lord Nottingham delimited a juridical form of conscience that was not religious but "civic and political". Meanwhile, his brilliant sister became a Quaker with the mystic Dr van Helmont.' ${ }^{55}$

A deeply important element of Conway's intellectual life was epistolary. She held an extraordinary 30-year conversation with Doctor Henry More, the Cambridge neo-Platonist who, through their correspondence, became a point of intellectual reference for her. Despite the social gulf between them, More the theologian also had contacts with Nottingham, Lord Chancellor and judge. Fulfilling the office of patron, Nottingham supported More and other divines - John Tillotson, Ralph Cudworth and Benjamin Whichcoat - associated with the Latitudinarian-Anglican circle at St Lawrence Jewry in London. ${ }^{56}$ This was not a matter of pure disinterest: 'Members of the legal profession, long at odds with the church's disciplinary machinery, ... provided opportunities for clerics who were willing to downplay the role of the church courts'. ${ }^{57}$ Nor, though in a different register, was the matter of Anne Conway's 1678 conversion to Quakerism. She encouraged More to meet with the Quaker leadership, including Penn, Keith and Fox. But following Lady Conway's 'scandalous' conversion, More wrote to her describing Nottingham's anything but tranquil reaction: 'What a peal my Lord Chancellour rang in my eares about your being turned Quaker, and what a storme I bore with be too long to rehearse in this letter'..$^{58}$

What looks interesting now would be to trace intersecting biographical paths between Nottingham, the elder brother-lawyer, and Anne Conway, the metaphysically inclined philosopher-sister. ${ }^{59}$ This would make for a

$55 \quad$ Saunders, above n 2, 29.

56 Ralph Cudworth dedicated his The True Intellectual System of the Universe (London, 1678) to Lord Nottingham, but in it he denounced the notion of a 'Publick Conscience'.

57 See WM Spelman, The Latitudinarians and the Church of England, 1660-1700 (Georgia University Press, 1993) 39-40.

58 Nicolson, above n 51, 430.

59 Anne Conway's metaphysical treatise, arguing that matter and body exist within an all-embracing spiritual substance, was published posthumously in Latin translation in 1690, this then being translated into English in 1692 as The Principles of the Most Ancient and Modern Philosophy: Concerning God, Christ, and the Creature; that is, concerning Spirit and Matter in General. See Sarah Hutton, Anne Conway. A Woman Philosopher (Cambridge University Press, 2004). 
historical comparison between judge and philosopher in respect of persona and office.

Nottingham's younger half-brother, Sir John Finch (1621-1682) is also part of the biographical picture. He was Henry More's student at Christ College, Cambridge. With Sir Thomas Baines - they were lifetime partners from their Cambridge days until the latter's death in Constantinople in 1681 - he left England in 1651, in a manner curiously like John Coke and Andrew Fountaine. John Finch would remain mostly abroad until just two years before his own death in 1683. He studied medicine at Padua, the centre of a neo-Aristotelian medicine grounded in empirical comparative anatomy, where William Harvey - linked by marriage to the Finch family - also studied. From Italy, John Finch served as a corresponding Fellow of the new Royal Society, among his contributions being a report on poisons.

In addition to such communications, John Finch corresponded with his family, with his sister Anne Conway in particular, as he travelled Europe. Over the years, he compiled a substantial manuscript treatise in the renaissance style of de omnia scibile, on all that can be known, ranging from local customs and laws to theology, from natural phenomena to politics, all observed within what we could very loosely term a materialist epistemology.$^{60}$ The treatise includes the author's sympathetic observations on Turkish practices, something made possible by John Finch's appointment in 1671 as English ambassador to the Ottoman court in Constantinople, where he remained until a year after Sir Thomas's death.

Having sketched these lives in outline, I'll close with two protocols for the biographical turn when describing early-modern lives. The first protocol is negative and concerns anachronism; the second is positive and concerns 'office'.

The negative protocol: avoid anachronism. Anachronism has two forms: either viewing the historical dead as prospectively pointing the way to what we happen to be now; or, viewing them as retrospectively assimilable to how we happen to be now. When Anne Conway is reclaimed as the first 'ecologist', the historical person is being inducted forward into our present preoccupations, as if these were timeless. Conversely, my previous reading of Lord Nottingham's demarcation of the two consciences as a fundamental separation of law from religion projected my 'secularisation' theory backward on to his 17th century situation. By retrospectively imputing law's disengagement from theology, I implied that 17th century English law was anticipating a modern 'secular' arrangement. My anachronism impeded historical description.

To grasp how the bearers of the early-modern Anglican polity conceptualised themselves, Jonathan Clark recommends we concentrate on 'talking not about class conflict, economic revolution or democratic representation but about hierarchy, allegiance and authority, concepts articulated within the practice of politics, law and religion'. ${ }^{61}$ This entails

$60 \quad$ Finch Papers, MS, DG7 lit, 9, Leicestershire County Record Office.

61 JCD Clark, Revolution and Rebellion: State and Society in England in the Seventeenth and Eighteenth Centuries (Cambridge University Press, 1986) 23. 
dropping 'much of the modern vocabulary of political science that is of nineteenth-century coinage, including the terms anarchism, bureaucracy, capitalism, communism, collectivism, conservatism, imperialism, individualism, and sociology'. If we wish to recover the historical reality of an English society that organised itself around the authority of immemorial custom, the common law and a Biblical order where spiritual things were not private and internal as they have since become, then we should add 'secularisation' to Clark's inventory of anachronisms to avoid.

Ahistorical anachronisms give too much to and take too much from a 17th century life such as Nottingham's. To those who persist in error, we should recite cite Conal Condren's curse: 'It is little better than giving up the ghost if we admit the anachronisms involved in our descriptive vocabulary and then proceed as if they do not matter' ${ }^{62}$

Avoiding anachronisms has implications for the biographical turn. It means - and this is the positive protocol - respecting the historical dead by describing their 17th century life-histories positively, that is, in terms they themselves could recognise. A crucial descriptive term is office. ${ }^{63}$ To describe these past lives in terms of an office occupied by an appropriate persona requires us to see these lives lived as an ensemble of duties performed, responsibilities met and purposes realised within a definite latitude of action, in Nottingham's case the latitude of the Anglican settlement.

With 17th century 'offices', we are somewhere else than in our modern non-office - even anti-office - psycho-world of intimate individualities, essential beings and hidden mechanisms of inner sovereign selves. In other words, we are at some distance from the 'novelistic' mode. Marjorie Hope Nicolson addresses the issue of Nottingham's reaction to his sister's embrace of Quakerism in novelistic mode:

Her influence may be detected not only in the treatment of Quakers in Ireland, but in the attitude toward those in England of Heneage Finch, both as Lord Keeper and as Lord Chancellor. Her brother, like her husband, had never refused a request of Anne Conway's. ${ }^{64}$

But as we have seen, Nottingham had most forcefully expressed his sense of scandal to Henry More. We need to decide where a 'novelistic' account stands in relation to the legal life-history?

To take a further instance, in her will, Anne Conway requested to be buried without 'pompous shewes and formalitys'. Following her death, as Nicolson recounts, 'Van Helmont devoted to her, dead, the skill which could not ease her, living', preparing a double coffin for her embalmed body. ${ }^{65}$ In the event, on 17 April 1679 her request was not met, her brother Nottingham preferring the full Anglican rites so that 'she might

62 Conal Condren, Argument and Authority in Early Modern England: the Presumption of Oaths and Offices (Cambridge University Press, 2006) 229.

63 Ibid, on the centrality of 'office' in historical description.

64 Nicolson, above n 51, 434.

65 Ibid, 452. 
be decently buried and not according to the humours of the Quakers that were about her'. ${ }^{66}$

Does a biographical turn that refuses anachronisms and deals in offices risk dulling our accounts of early-modern lives? Two comments by David Yale suggest it might seem so. First, it is difficult to disentangle [Nottingham's] private opinions from his presentation of the official case'. ${ }^{67}$ It's as though we're missing an essential element, access to the subject's interiority, his 'private opinions'. Second, '[his conduct as a judge] appears to have been part and parcel of his life, so correct and consistent that it almost loses interest for anyone not attracted by the further fascination of his work in court'. ${ }^{68}$ Where accounts of lives and offices are concerned, this leaves 'fascination' at the door, relegated to material for technical specialists only. It's as if office effaces affect.

Perhaps it's wrong to be unequivocal on this. Matthew Hale would have had the most anxious of a judge's sleepless nights on the eve of the witches' trial, torn between his office of Puritan drawn by conscience to the suffering of the women whom he was to sentence to death and the impartiality he owed to his office of common-law judge. Or we might disapprove of Nottingham's opting for his sister to be buried with full Anglican rites but we cannot doubt his affection on this matter of extreme sensitivity - the kindred partiality towards the sister to be buried - as was due to his office of brother. A biographical turn in the direction of offices need not be dull. We read of Lord Nottingham that, 'Perhaps his one eccentricity was to take the Great Seal to bed with him, thus avoiding the accident that later befell Lord Thurlow, for on 7 February the mace was stolen out of his [Thurlow's] house in Queen Street'. ${ }^{69}$ Dull? Affectless? Taking the Great Seal to bed could be irresistible evidence of a life of office that was being lived to the very full.

\footnotetext{
$\overline{66}$ Hutton, Anne Conway, above n 59, 216.

67 Yale, 'Introduction', above n 34, xxiv.

68 Ibid, xxxi.

69 Ibid, xxxvi.
} 